\title{
Peer-to-Peer Lending Syariah dan Dampaknya terhadap Kinerja serta Kesejahteraan Pelaku Usaha Mikro dan Kecil (UMK) pada Masa Pandemi Covid-19
}

\author{
Sharia Peer-to-Peer Lending and Its Impact on the Performance and Welfare of \\ Micro and Small Business Enterprises (MSEs) during the Covid-19 Pandemic
}

\author{
Aphylla Planifolia Harp ${ }^{1}$, Resfa Fitri ${ }^{2}$, Yekti Mahanani ${ }^{3}$ \\ IFakultas Ekonomi dan Manajemen, Institut Pertanian Bogor, Jalan Raya Dramaga, Bogor 16680, \\ Indonesia, aphylla_via@apps.ipb.ac.id \\ ${ }^{2}$ Fakultas Ekonomi dan Manajemen, Institut Pertanian Bogor, Jalan Raya Dramaga, Bogor 16680, \\ Indonesia, resfa_fitri@apps.ipb.ac.id \\ ${ }^{3}$ Fakultas Ekonomi dan Manajamen, Institut Pertanian Bogor, Jalan Raya Dramaga, Bogor 16680, \\ yektimahanani@apps.ipb.ac.id
}

\begin{abstract}
Peer-to-Peer (P2P) lending is one of the mechanisms to overcome capital problems for the MSE sector, especially during the Covid-19 pandemic. P2P lending has the highest asset growth compared to other financial technology (fintech) schemes and mostly preferred by the majority of population. As a country with a majority Muslim population, people prefer to use sharia P2P lending, but its role has not been widely documented in the literature. MSEs are business enterprises that contribute greatly to the national gross domestic product (GDP) and absorb the most labor. This study aims to analyze the effect of sharia $(P 2 P)$ lending on the performance and welfare of MSEs during the Covid-19 pandemic. The method of analysis consists of paired t-test, OLS and logistic regression analysis. Paired t-test results show that there are differences in turnover, profits, operating costs, and the number of MSE workers before and after receiving financing. OLS analysis shows that the amount of financing, business costs, labor, and length of business affect changes in MSE turnover. The results of the logistic regression analysis show that the average family income and the amount of savings significantly affect the welfare of MSE actors.
\end{abstract}

Keywords: MSEs, performance, sharia financing, sharia peer-to-peer $(P 2 P)$ lending, welfare.

\begin{abstract}
Abstrak. Peer-to-Peer (P2P) lending merupakan salah satu mekanisme untuk mengatasi masalah permodalan bagi sektor UMK, khususnya di masa pandemi Covid-19. $P 2 P$ lending memiliki pertumbuhan aset tertinggi dibandingkan skema teknologi finansial (fintech) lainnya dan sangat disukai oleh sebagian besar masyarakat. Sebagai negara dengan mayoritas penduduknya beragama Islam, masyarakat Indonesia lebih memilih menggunakan P2P lending syariah, namun perannya belum banyak terdokumentasi dalam literatur. UMK merupakan kelompok usaha yang memberikan kontribusi besar terhadap produk domestik bruto (PDB) nasional dan paling banyak menyerap tenaga kerja. Penelitian ini bertujuan untuk menganalisis pengaruh pembiayaan $P 2 P$ lending syariah terhadap kinerja dan kesejahteraan pelaku UMK pada masa pandemi Covid-19. Metode penelitian terdiri dari Uji-t berpasangan, OLS dan analisis regresi logistik. Hasil Uji-t berpasangan menunjukkan bahwa terdapat perbedaan omzet, keuntungan, biaya usaha, dan jumlah tenaga kerja UMK antara sebelum dan sesudah mendapatkan pembiayaan. Analisis OLS menunjukkan bahwa jumlah pembiayaan, biaya usaha, tenaga kerja, dan lama usaha memengaruhi perubahan omzet UMK. Hasil analisis regresi logistik menunjukkan bahwa pendapatan rata-rata keluarga dan jumlah tabungan memengaruhi kesejahteraan pelaku UMK secara signifikan.
\end{abstract}

Kata kunci: Kesejahteraan, kinerja, peer-to-peer $(P 2 P)$ lending syariah, pembiayaan syariah, UMK.

\section{PENDAHULUAN}

Fenomena digitalisasi saat ini menjadi salah satu pokok bahasan utama dalam era Revolusi Industri 4.0, termasuk di Indonesia. Bappenas (2018) memprediksi pada tahun 2025 ekonomi digital Indonesia mencapai nilai US\$240 miliar. Hal tersebut membuat Indonesia menjadi pasar potensial ekonomi 
digital terbesar di kawasan Asia Tenggara. Dalam perkembangan ekonomi digital, salah satu sektor terdigitalisasi yang pertumbuhannya sangat pesat adalah financial technology atau dalam Bahasa Indonesia disebut teknologi finansial. Teknologi finansial adalah penggunaan teknologi dalam sistem keuangan yang menghasilkan produk, layanan, teknologi, atau model bisnis baru yang dapat berdampak pada stabilitas moneter, sistem keuangan, kelancaran, keamanan, dan keandalan sistem pembayaran (Bank Indonesia, 2017).

Menurut Bappenas (2018) dalam Masterplan Ekonomi Syariah Indonesia 2019-2024, skema financial technology atau fintech yang mempunyai kontribusi paling besar dan memiliki pertumbuhan aset tertinggi adalah Peer-to-Peer $(P 2 P)$ lending. Perusahaan fintech P2P lending memberikan fasilitas kepada pihak yang membutuhkan dana pinjaman (borrower) dengan para pihak yang ingin berinvestasi (lender) untuk memberikan pembiayaan tanpa perlu mengunjungi kantor perusahaan $P 2 P$ lending.

Berdasarkan data Otoritas Jasa Keuangan (OJK), per Maret 2020 jumlah P2P lending yang terdaftar atau berizin ada 161 perusahaan dengan detail 149 perusahaan konvensional dan 12 perusahaan berdasarkan prinsip syariah. Sampai saat ini, $P 2 P$ lending di Indonesia telah menyalurkan pinjaman sebesar Rp74.54 triliun dengan jumlah akumulasi rekening lender sebanyak 591,662 entitas dan jumlah akumulasi rekening borrower sebanyak 17,244,998 entitas. Akumulasi penyaluran pinjaman perusahaan $P 2 P$ lending di Indonesia mengalami peningkatan yang pesat dari tiga triliun rupiah pada Januari 2018, menjadi tiga belas triliun rupiah pada September 2018 dan terus tumbuh hingga pada Maret 2020 mencapai seratus dua triliun rupiah (OJK, 2020). Perusahaan P2P lending menyediakan berbagai layanan, yaitu pembiayaan konsumtif dan pembiayaan produktif. Salah satu layanan pembiayaan produktif yang disediakan oleh perusahaan $P 2 P$ lending adalah pembiayaan untuk kelompok usaha mikro dan kecil (UMK).

Berdasarkan data dari Kementerian Koperasi dan Usaha Mikro, Kecil, dan Menengah, sejak pasca krisis ekonomi tahun 1997-1998 jumlah UMK tidak mengalami penurunan, sebaliknya terus mengalami peningkatan jumlah unit usaha (Tabel 1). Per Desember 2018, kelompok usaha mikro, kecil dan menengah memberikan kontribusi sebesar $61.07 \%$ dari total keseluruhan produk domestik bruto (PDB) Indonesia dengan nominal 14,038,598.5 milyar rupiah (Kemenkop, 2018). Kelompok usaha mikro dan kecil juga berkontribusi besar terhadap penyerapan tenaga kerja di Indonesia. UMK menyerap 93\% dari total seluruh jumlah tenaga kerja di Indonesia dengan angka sebanyak 113,207,796 tenaga kerja. Hal tersebut membuktikan bahwa kelompok usaha mikro dan kecil (UMK) memiliki peran yang besar dalam mengurangi angka pengangguran dan memiliki peran yang sangat penting dalam upaya pengentasan kemiskinan.

Tabel 1 Perkembangan jumlah usaha mikro dan kecil di Indonesia tahun 2016-2018

\begin{tabular}{cccc}
\hline Tahun & Jumlah Usaha Mikro & Jumlah Usaha Kecil & Total UMK \\
\hline 2016 & $60,863,578$ & 731,047 & $61,594,625$ \\
2017 & $62,106,900$ & 757,090 & $62,863,990$ \\
2018 & $63,350,222$ & 783,132 & $64,133,354$ \\
\hline
\end{tabular}

Sumber: Kementerian Koperasi dan UMKM, 2018 (diolah).

Pentingnya peran UMK membuat kelompok usaha ini perlu dikembangkan dalam rangka mengurangi tingkat pengangguran dan kemiskinan di Indonesia. Namun pada kenyataannya, usaha mikro dan kecil (UMK) memiliki banyak keterbatasan yang membuat UMK sulit untuk berkembang dan memiliki daya saing. Salah satu permasalahan yang menjadi kendala utama UMK adalah akses terhadap sumber pembiayaan (Rachbini dan Hamid, 1994).

Persentase usaha mikro dan kecil yang memerlukan kredit tetapi tidak memiliki akses ke lembaga keuangan sebesar $80 \%$ dari total usaha mikro dan kecil di Indonesia, sedangkan persentase usaha mikro dan kecil yang memiliki akses ke lembaga keuangan dan mendapatkan kredit hanya sebesar 
$20 \%$ dari total usaha mikro dan kecil di Indonesia (BPS, 2016). Hal ini disebabkan akses terhadap pinjaman bank dinilai tidak mudah. Berdasarkan kajian BPPP Kemendag (2013), kecilnya persentase UMK yang mendapatkan kredit disebabkan tiga kendala utama dari aspek lembaga pembiayaan, yaitu sulitnya menilai UMK yang memenuhi persyaratan pemberian kredit yang ditetapkan oleh lembaga pembiayaan, animo UMK yang rendah terhadap upaya pembinaan oleh lembaga pembiayaan, dan sebagian besar pengelolaan keuangan UMK masih belum memisahkan antara keuangan pribadi dengan keuangan usaha.

Usaha mikro dan kecil (UMK) yang tidak memiliki akses terhadap permodalan biasanya terperangkap dalam vicious cycle. UMK yang terperangkap dalam vicious cycle tidak dapat mengeluarkan pelaku usaha dari kemiskinan. Fenomena kemiskinan akan terus berlanjut tanpa henti dan saling memengaruhi. Proses kemiskinan diawali dengan ketidaksempurnaan pasar yang menyebabkan keterbelakangan. Keterbelakangan membuat masyarakat kekurangan modal yang memengaruhi rendahnya produktivitas.

Produktivitas rendah menghasilkan pendapatan rendah yang berimplikasi pada rendahnya kemampuan menabung dan investasi rendah. Dampak lanjutan dari investasi rendah akan memperburuk perekonomian dan mengakibatkan keterbelakangan ekonomi dan masyarakat tertinggal (Nurkse, 1953).

Usaha berskala mikro dan kecil mayoritas dimulai dari masyarakat miskin yang mengalami keterbatasan terhadap akses permodalan. Hal ini membuat pelaku usaha mikro tetap memiliki pendapatan rendah yang berdampak pada jumlah tabungan dan investasi rendah karena tidak adanya solusi untuk memutus siklus tersebut dan dapat membuat usaha mikro berkembang.

Berdasarkan data Kementerian Koordinator Bidang Perekonomian Republik Indonesia (2020), jumlah UMK yang mendapatkan bantuan pembiayaan Kredit Usaha Rakyat (KUR) baru mencapai 4,650,162 debitur. Jika dibandingkan dengan jumlah usaha mikro saat ini yang mencapai 64,194,057 unit usaha, jumlah tersebut baru mencapai $7.24 \%$ dari total UMK di Indonesia. Ketidakmampuan lembaga keuangan formal untuk melayani kebutuhan UMK terhadap akses pembiayaan atau permodalan menimbulkan kesenjangan pembiayaan (financial gap) sehingga dibutuhkan solusi alternatif pembiayaan melalui $P 2 P$ lending syariah yang dapat membantu memecahkan permasalahan permodalan usaha mikro dan kecil (UMK).

Literatur tentang digitalisai pembiayaan syariah khususnya tentang $P 2 P$ lending syariah masih jarang bahkan hampir tidak ada. Oleh karena itu, penelitan ini dilakukan untuk mengisi kekosongan literatur dan melihat pengaruh pembiayaan $P 2 P$ lending syariah terhadap kinerja UMK dan kesejahteraan pelaku UMK. Penelitian ini mempunyai dua tujuan utama. Pertama untuk menganalisis pengaruh $P 2 P$ lending syariah terhadap kinerja UMK serta mengidentifikasi faktor-faktor apa saja yang mempengaruhinya. Kedua untuk menganalisis pengaruh $P 2 P$ lending syariah terhadap peningkatan kesejahteraan UMK serta mengidentifikasi faktor-faktor yang mempengaruhinya.

\section{TINJAUAN PUSTAKA}

\section{Konsep Peer-to-Peer (P2P) Lending}

Menurut Peraturan OJK Nomor 77/2016, Peer-to-Peer (P2P) lending atau Layanan Pinjam Meminjam Uang Berbasis Teknologi Informasi adalah penyelenggaraan layanan jasa keuangan untuk mempertemukan pemberi pinjaman dengan penerima pinjaman dalam rangka melakukan perjanjian pinjam meminjam secara langsung melalui sistem elektronik dengan jaringan internet. Sistem $P 2 P$ lending sangat mirip dengan konsep marketplace tetapi untuk kegiatan pinjam-meminjam uang secara online (Tampubolon, 2019). P2P lending menyediakan wadah atau sistem yang akan mempertemukan pihak pemberi pinjaman dan pihak peminjam. Dalam platform $P 2 P$ lending, terdapat peminjam (borrower) atau penerima pembiayaan dengan berbagai macam level risiko default yang 
sedang mencari sumber likuiditas, serta pendana (lender) yang dapat melihat adanya kesempatan untuk berinvestasi dalam rangka mendapatkan keuntungan pada suatu level risiko tertentu (Greiner dan Wang, 2009).

Subjek dalam $P 2 P$ lending ada tiga pihak, yaitu penyelenggara (perusahaan penyedia layanan $P 2 P$ lending), penerima pembiayaan (borrower) dan pemberi pembiayaan (lender). Hubungan antara ketiga subjek tersebut dapat dilihat pada skema sederhana layanan P2P lending pada Gambar 2. Pada skema layanan $P 2 P$ lending tersebut, pihak lender sebagai pemberi pembiayaan menyampaikan pembiayaannya melalui perusahaan $P 2 P$ lending menggunakan digital platform $P 2 P$ lending kepada pihak borrower, dalam hal ini adalah Usaha Mikro dan Kecil (UMK). Pinjaman melalui $P 2 P$ lending menguntungkan berbagai pihak. Bagi peminjam atau penerima pembiayaan, $P 2 P$ lending adalah cara untuk mendapatkan pinjaman dengan lebih mudah daripada meminjam lewat sistem perbankan tradisional. P2P lending mudah karena semua prosesnya dilakukan secara daring sehingga menjadi lebih mudah dan cepat.

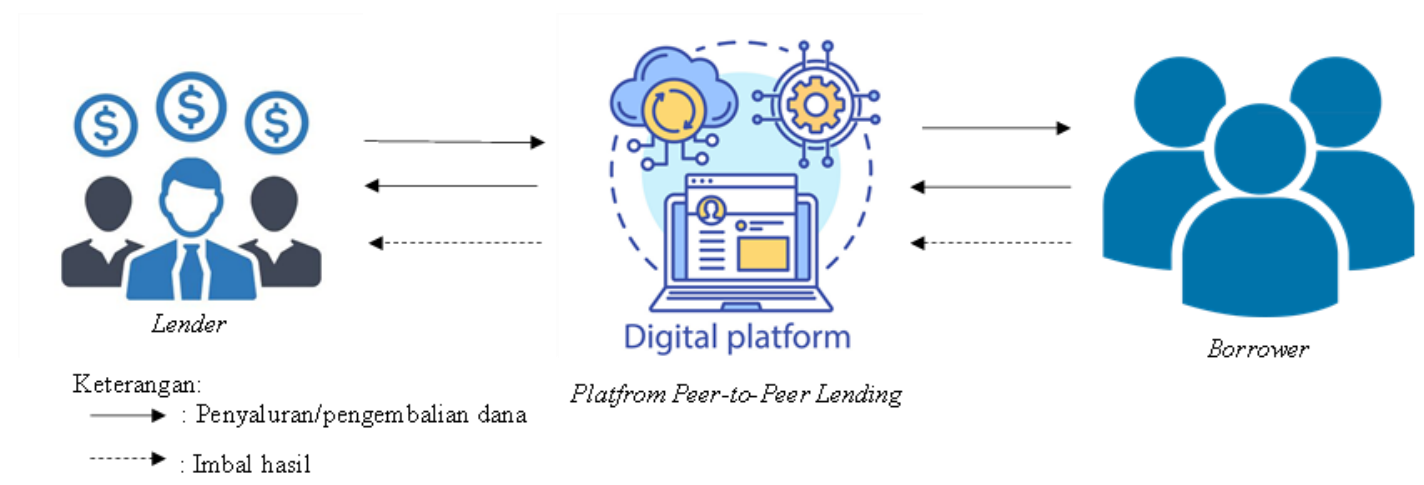

Sumber: Baihaqi, 2018

Gambar 2 Skema layanan P2P lending

Platform $P 2 P$ lending menyaring kelayakan calon dengan melakukan pemeriksaan terhadap riwayat kredit dan alamat peminjam dan menggunakan teknologi Artificial Inteligence (AI) atau konsultan otomatis untuk menganalisa big data. Teknologi artificial inteligence mampu membuat portofolio untuk diberikan kepada akun investor berdasarkan algoritma yang diperhitungkan menggunakan informasi seperti usia, toleransi risiko dan keengganan, pendapatan bersih, status keluarga, serta informasi lainnya yang didapatkan melalui kuesioner online yang disediakan oleh perusahaan $P 2 P$ lending. Teknologi analisis Big Data dan Artificial Inteligence membantu menangani manajemen risiko dan membuat biaya operasional lebih efisien sehingga profil peminjam yang akan disetujui lebih berkualitas dan menurunkan kemungkinan gagal bayar (Giudici, 2018).

\section{P2P Lending Syariah}

Menurut fatwa DSN MUI Nomor 117/DSN-MUI/II/2018, P2P lending syariah didefinisikan sebagai penyelenggaraan layanan jasa keuangan yang didasarkan atas prinsip syariah yang menghubungkan antara pemberi pembiayaan dengan penerima pembiayaan untuk melakukan akad pembiayaan melalui sistem elektronik dengan bantuan jaringan internet. Perbedaan $P 2 P$ lending syariah dan konvensional terletak pada sistem transaksi yang digunakan. $P 2 P$ lending syariah menggunakan prinsip dan aturan Islam atau syariah dalam menjalankan kegiatan operasionalnya. Contohnya menggunakan prinsip bagi hasil dan menggunakan akad-akad syariah. Karakteristik tersebut berbeda dengan $P 2 P$ lending konvensional yang hanya menggunakan hukum positif yang berlaku. Selain itu $P 2 P$ lending konvensional menggunakan sistem bunga dengan besar yang relatif beragam mulai dari $30 \%$. 
Ketentuan prinsip syariah dalam P2P lending syariah menurut Baihaqi (2018) yaitu, (1) terhindari dari riba, gharar (ketidakpastian), maysir (spekulasi), tadlis (menyembunyikan cacat), dharar (merugikan pihak lain), dan haram; (2) memenuhi prinsip keseimbangan, keadilan, dan kewajaran sesuai syariah dan peraturan perundang-undangan yang berlaku; (3) akad yang digunakan selaras dengan karakteristik layanan pembiayaan seperti al-bai', ijarah, mudharabah, musyarakah, wakalah bi al ujrah, dan qardh; (4) terdapat bukti transaksi berupa sertifikat elektronik dan telah divalidasi; (5) transaksi harus menjelaskan ketentuan bagi hasil yang sesuai dengan syariah, dan (6) penyelenggaraan layanan boleh mengenakan biaya (ujrah) dengan prinsip ijarah.

\section{Kinerja Usaha Mikro, Kecil dan Menengah (UMKM)}

Menurut Undang-Undang Republik Indonesia Nomor 20 tahun 2008, usaha mikro adalah usaha produktif milik perorangan atau badan usaha perorangan yang memiliki nilai aset kurang dari 50 juta rupiah, jumlah omzet kurang dari 300 juta rupiah, dan menggunakan tenaga kerja sebanyak 1-4 orang. Usaha kecil adalah usaha produktif milik perorangan atau badan usaha perorangan yang memiliki nilai aset 50 juta-500 juta rupiah, jumlah omzet sebesar 300 juta- 2.5 miliar rupiah, dan menggunakan tenaga kerja sebanyak 5-19 orang.

Kinerja UMKM dapat diukur melalui tiga aspek yaitu profitabilitas, produktivitas dan aspek pasar (Aragón-Sánchez dan Sánchez-Marín, 2005). Aspek profitabilitas dapat dilihat dari kinerja profitabilitas dan kinerja profitabilitas dapat diukur melalui jumlah pendapatan usaha dan kemampuan perusahaan untuk membayar angsuran. Aspek produktivitas merupakan istilah dalam kegiatan produksi di mana dilakukan kegiatan penilaian dengan membandingkan antara output dengan input. Produktivitas merupakan ukuran yang menyatakan seberapa efektif dan efisien sumber daya yang ada untuk diatur dan dimanfaatkan dalam rangka mencapai hasil optimal.

Selain dilihat dari aspek profitabilitas dan produktivitas pengukuran kinerja UMKM juga dapat diukur dari aspek pasar. Kinerja pemasaran merupakan suatu ukuran keberhasilan dari aktivitas proses pemasaran secara menyeluruh sebuah perusahaan. Pemasaran berkontribusi besar dalam penciptaan nilai perusahaan dan penilaian kinerja jangka panjang walaupun laporan keuangan tidak dapat mengukur manfaat ekonominya. Kinerja pasar yang baik akan mempengaruhi harapan investor terhadap tingkat penjualan dan nilai suatu perusahaan.

Tingkat keberhasilan kinerja UMKM juga dapat diukur dari beberapa indikator berikut antara lain: tingkat pertumbuhan penjualan/omzet penjualan yang meningkat, tingkat pertumbuhan modal yang meningkat, tingkat pertumbuhan tenaga kerja yang tinggi, tingkat pertumbuhan pasar yang luas, dan tingkat pertumbuhan keuntungan yang terus meningkat (Rokhayati, 2015).

Beberapa penelitian untuk menganalisis pengaruh pembiayaan terhadap kinerja UMKM telah dilakukan di beberapa negara seperti Indonesia, Malaysia, dan Tiongkok. Hasil penelitian Nurdana (2018), Amrani et al. (2018), Pei-Wen et al. (2016), Tunas et al. (2014), dan Wang (2013) menunjukkan bahwa pinjaman atau pembiayaan yang diberikan oleh Lembaga Keuangan Mikro (LKM) kepada UMKM memberikan dampak yang positif terhadap kinerja UMKM yang diukur melalui variabel omzet usaha atau laba bersih usaha. Hasil yang berbeda diperoleh dari penelitian Hidayati et al. (2014) yang menganalisis faktor-faktor yang memengaruhi realisasi pembiayaan mikro syariah dan dampaknya terhadap omzet usaha nasabah menyatakan bahwa pembiayaan yang diberikan oleh Lembaga Keuangan Mikro Syariah berpengaruh negatif terhadap omzet usaha.

\section{Pengaruh Pembiayaan P2P Lending bagi UMK dan Perekonomian Indonesia}

Wijaya (2016) menyatakan bahwa layanan P2P lending memberikan manfaat bagi perekonomian Indonesia, termasuk dalam menyelesaikan beberapa masalah yang terkait dengan kesejahteraan UMKM. $P 2 P$ lending dapat membantu meningkatkan taraf inklusi keuangan terhadap masyarakat Indonesia. Sekitar 80\% UMK belum mendapatkan akses atau pembiayaan perbankan (BPS, 2016). 
Hal ini disebabkan pinjaman modal usaha memiliki syarat untuk menyertakan agunan atau jaminan dalam prosesnya. $P 2 P$ lending dapat menjangkau usaha mikro dan kecil (UMK) yang belum memiliki akses terhadap perbankan (unbankable) dan menjembatani UMK yang sebenarnya layak (credit worthy) agar mendapatkan pinjaman baik dengan atau tanpa agunan.

$P 2 P$ lending juga memberikan solusi terhadap tidak meratanya ketersediaan layanan pembiayaan. Di Indonesia, 60\% layanan pembiayaan terkonsentrasi hanya di Pulau Jawa. Penggunaan jaringan internet membuat $P 2 P$ lending mampu menjangkau hampir siapa saja dan di mana saja selama terdapat akses terhadap internet serta menjadikan proses administrasi pinjaman efektif dan efisien. Selanjutnya, P2P lending dapat menjadi solusi untuk mengurangi kesenjangan pembiayaan pembangunan di Indosnesia. Lembaga keuangan yang ada di Indonesia saat ini hanya mampu menyerap sekitar 700 triliun rupiah dari total kebutuhan pembiayaan pembangunan sebesar 1,700 triliun per tahunnya. P2P lending menawarkan overhead yang rendah dengan credit scoring dan algoritma inovatif yang dapat membantu mengurangi kesenjangan pada kebutuhan pembiayaan pembangunan di Indonesia (Wijaya, 2016).

\section{METODE}

Penelitian ini menggunakan metode uji-t berpasangan, Ordinary Least Square (OLS) dan analisis regresi logistik. Uji-t berpasangan digunakan untuk membandingkan perbedaan rata-rata antara kinerja UMK sebelum dan setelah menerima pembiayaan dari P2P lending syariah. Metode analisis ordinary least square $(O L S)$ digunakan untuk mengidentifikasi faktor-faktor yang memengaruhi kinerja UMK. Analisis regresi logistik digunakan untuk mengidentifikasi faktor-faktor yang memengaruhi peluang peningkatan kesejahteraan pelaku UMK berdasarkan opini responden.

Penelitian ini difokuskan pada salah satu perusahaan $P 2 P$ lending syariah yang memberikan perhatian khusus pada pembiayaan kelompok usaha mikro dan kecil yaitu PT Ammana Fintek Syariah. Pemilihan studi kasus ini didasarkan pada beberapa fakta, yaitu PT Ammana Fintek Syariah merupakan $P 2 P$ lending berbasis syariah yang pertama kali berdiri di Indonesia dan menjadi satusatunya $P 2 P$ lending syariah yang juga menyalurkan pembiayaan skala mikro sehingga memberikan kesempatan lebih luas bagi usaha mikro untuk mendapatkan bantuan modal. Berdasarkan data dari website Ammana Fintek Syariah per Mei 2020, perusahaan ini telah menyalurkan pendanaan sebesar 35 miliar rupiah sejak berdiri dan memiliki jumlah penerima pendanaan sebanyak 2288 entitas dengan jumlah mitra sebanyak 70 Koperasi Simpan Pinjam dan Pembiayaan Syariah (KSPPS) dan BMT.

Data yang digunakan dalam penelitian ini adalah data primer yang diperoleh dari wawancara langsung dengan pelaku usaha mikro dan kecil (UMK) yang telah menerima pembiayaan dari Ammana Fintek Syariah melalui BMT Dana Ukhuwah dan BMT Mitra Madani. Wawancara dengan pemilik usaha mikro dan kecil (UMK) bertujuan menganalisis pengaruh pembiayaan yang diberikan PT Ammana Fintek Syariah terhadap kinerja dan kesejahteraan pelaku UMK serta untuk mengidentifikasi faktorfaktor yang memengaruhinya.

Objek dari penelitian ini adalah usaha mikro dan kecil (UMK) anggota BMT Dana Ukhuwah dan BMT Mitra Madani yang bekerja sama dengan PT Ammana Fintek Syariah. BMT tersebut dipilih karena memiliki banyak mitra UMK yang telah menerima pembiayaan dengan jumlah sebanyak 134 UMK. Teknik pengambilan sampel yang digunakan adalah purposive sampling. Purposive sampling adalah salah satu teknik sampling non-probability sampling di mana peneliti menentukan pengambilan sampel dengan menetapkan kriteria khusus yang sesuai dengan tujuan penelitian. Purposive sampling digunakan dengan tujuan untuk mendapatkan informasi yang tersedia terhadap kelompok tertentu yang sesuai dengan subjek penelitian (Sumarwan et al. 2014). Kriteria sampel yang dikategorikan dalam penelitian ini adalah UMK yang telah menerima pembiayaan dari Ammana Fintek Syariah dan telah selesai melakukan angsuran pembiayaan. 
Penetapan jumlah sampel sesuai pendapat Sumarwan et al. (2014), bahwa untuk menganalisis suatu kelompok digunakan sampel sebanyak 30 sampel per kelompok. Penetapan jumlah sampel didukung oleh aturan praktis yang dikemukakan oleh Roscoe (1975 dalam Sekaran, 2003) bahwa ukuran sampel lebih besar dari 30 dan kurang dari 500 sesuai untuk sebuah penelitian. Selain itu, karena penelitian ini menggunakan kuesioner untuk pengumpulan data, maka dibutuhkan pengambilan sampel untuk melakukan uji reliabilitas dan validitas. Jumlah sampel yang digunakan dalam uji coba kuesioner berjumlah minimal 30 responden (Singarimbun dan Efendi, 1995).

\section{Paired Sample t-Test (Uji Beda Berpasangan)}

Uji beda berpasangan digunakan untuk menganalisis apakah terdapat perbedaan rata-rata antara dua sampel tidak bebas yang sama namun mengalami proses pengukuran maupun perlakuan yang berbeda (Nugroho, 2005). Penelitian ini ingin membandingkan perbedaan keuntungan UMK sebelum dan sesudah mendapatkan pembiayaan dari peer-to-peer lending syariah, studi kasus PT Ammana Fintek Syariah. Hipotesis yang diusulkan untuk diuji dalam penelitian ini adalah $\mathrm{H}_{0}$ : diduga tidak ada perbedaan keuntungan UMK antara sebelum dan sesudah pemberian pembiayaan dan $\mathrm{H}_{1}$ : diduga ada perbedaan keuntungan UMK antara sebelum dan sesudah pemberian pembiayaan. Variabel yang digunakan pada uji beda berpasangan yaitu omzet usaha, keuntungan, biaya usaha, dan jumlah tenaga kerja. Uji-t berpasangan dapat dituliskan dalam rumus matematika sebagai berikut (Nugroho, 2005).

$$
\mathrm{t}_{\text {hitung }}=\frac{\overline{\mathrm{d}}}{\mathrm{Sd} \sqrt{\mathrm{n}}}
$$

Keterangan:

$$
\begin{aligned}
& \mathrm{d}=\mathrm{x}_{1}-\mathrm{x}_{2} \\
& \overline{\mathrm{d}}=\sum \frac{\mathrm{d}}{\mathrm{m}} \\
& \mathrm{S}_{\mathrm{d}}=\sqrt{\frac{\sum \mathrm{d}^{2}-\frac{(\Sigma \mathrm{d})^{2}}{n}}{\mathrm{n}-1}}
\end{aligned}
$$

\section{Ordinary Least Square (OLS)}

Ordinary Least Square adalah teknik estimasi regresi yang berfungsi untuk meminimalisir jumlah error. Model OLS berfungsi untuk mengetahui hubungan antara variabel terikat dengan masingmasing variabel bebas (Studenmund, 2016). Menurut Gujarati dan Porter (2009), koefisien estimasi yang digunakan pada model OLS harus bersifat BLUE (Best Linear Unbiased Estimator) yaitu:

1. Linear, artinya estimatior OLS merupakan fungsi linear dari variabel acak seperti variabel bebas dalam model regresi.

2. Unbiased, artinya nilai rata-rata atau nilai ekspektasi dari estimator sama mendekati nilai yang sebenarnya.

3. Efficient, artinya estimator OLS memiliki varian minimum untuk memastikan bahwa estimator efisien.

Agar penelitian ini menghasilkan koefisien estimasi yang bersifat BLUE, maka patut dilakukan pengujian asumsi klasik yang terdiri dari uji normalitas, uji multikolinearitas, uji heteroskedastisitas, dan uji autokorelasi. Model matematis dari OLS yang digunakan pada penelitian ini diturunkan dari model penelitian Nurdana (2018) dan Tunas et al. (2014). Beberapa variabel yang diduga memengaruhi keuntungan UMK yaitu jumlah pembiayaan, jumlah biaya usaha, jumlah tenaga kerja (Nurdana, 2018). Selain itu, variabel lain yang diduga memengaruhi keuntungan UMK yaitu lama usaha, frekuensi pembiayaan dan lama pendidikan (Tunas et al., 2014). Model pada penelitian ini dituliskan sebagai berikut: 
$\Delta$ Keuntungan Usaha $=\beta_{0}+\beta_{1 \mathrm{i}} \mathrm{X}_{1}+\beta_{2 \mathrm{i}} \mathrm{X}_{2}+\beta_{\mathrm{qi}_{\mathrm{i}}} \mathrm{X}_{3}+\beta_{4 \mathrm{i}} \mathrm{X}_{4}+\beta_{5 \mathrm{i}} \mathrm{X}_{5}+\beta_{6 \mathrm{i}} \mathrm{D}_{1}+\varepsilon_{i}$

Di mana:

$\Delta$ Keuntungan Usaha $=$ Perubahan keuntungan UMK setelah mendapatkan pembiayaan

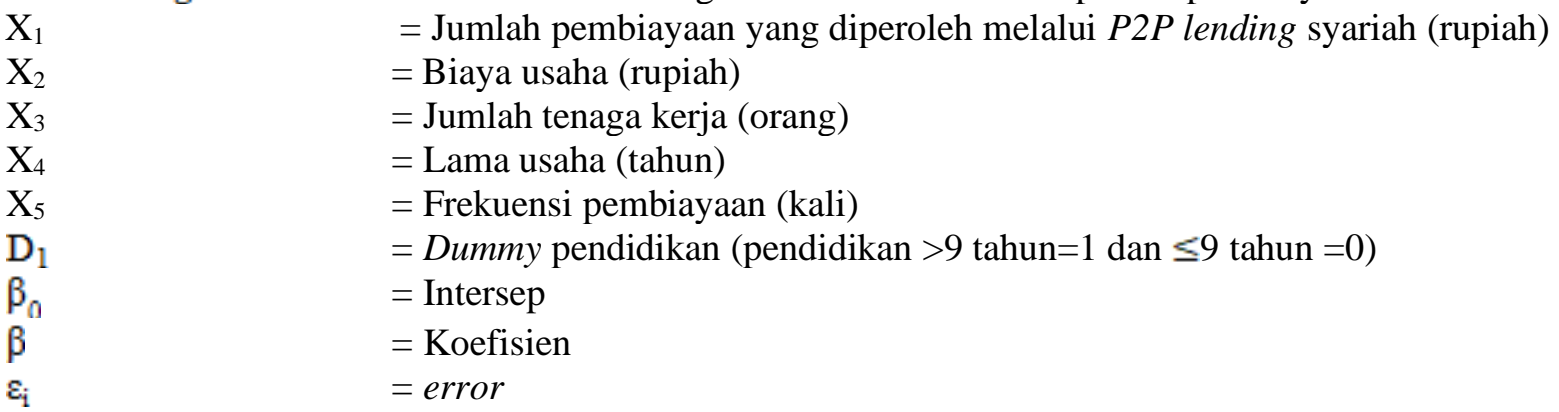

\section{Analisis Regresi Logistik}

Analisis regresi logistik digunakan untuk menjelaskan hubungan antara variabel respon yang berupa data dikotomik atau biner dengan variabel bebas yang berupa data berskala interval dan atau kategorik (Firdaus et al., 2011). Variabel dikotomik atau biner adalah variabel yang hanya memiliki dua kategori saja, yaitu kategori yang menyatakan kejadian sukses $(\mathrm{Y}=1)$ dan kategori yang menyatakan kejadian gagal $(\mathrm{Y}=0)$. Kesejahteraan pelaku usaha mikro dan kecil dinilai berdasarkan skor persepsi kesejahteraan yang terdapat pada kuesioner dan telah diisi oleh responden. Penelitian ini mengacu pada penelitian yang dilakukan oleh Sari et al. (2014), di mana klasifikasi kesejahteraan yang digunakan terdiri dari dua klasifikasi yaitu, pelaku usaha sejahtera dan belum sejahtera. Untuk mengukur masing-masing klasifikasi kesejahteraan digunakan rumus penentuan range score sebagai berikut:

$$
\mathrm{RS}=\frac{\mathrm{Sk} \mathrm{T}-\mathrm{SkR}}{\mathrm{K} 1}
$$

Keterangan:

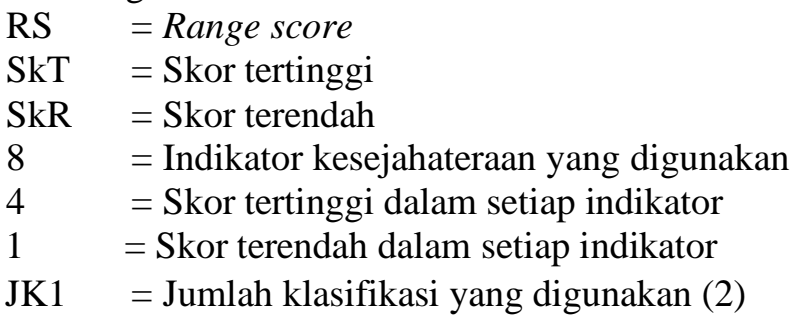

Hasil perhitungan berdasarkan rumus diperoleh range score (RS) sama dengan dua belas, sehingga tingkat kesejahteraan pelaku usaha mikro dan kecil diklasifikasikan sebagai berikut:

1. Jika range score antara $12-24$, maka pelaku usaha digolongkan belum sejahtera dan diberi nilai 0.

2. Jika range score antara 25-32, maka pelaku usaha digolongkan sejahtera dan diberi nilai 1.

Model regresi logistik yang digunakan pada penelitian ini mengacu pada penelitian Gina dan Effendi (2015). Beberapa variabel yang diduga memengaruhi peluang peningkatan kesejahteraan pelaku UMK yaitu, lama menjadi anggota, kepemilikan aset, jumlah pembiyaan yang diterima, jumlah pendapatan rata-rata keluarga, pengeluaran makanan, biaya kesehatan, biaya pendidikan, dan jumlah tabungan. Adapun model regresi logistik yang digunakan adalah sebagai berikut: 


$$
\operatorname{Ln}\left[\frac{P_{i}}{1-P i}\right]=\beta_{i}+\beta_{1} X_{1}+\beta_{2} X_{2}+\beta_{3} X_{3}+\beta_{4} x_{4}+\beta_{5} X_{5}+\beta_{6} x_{6}+\beta_{7} X_{7}+\beta_{8} X_{8}+\varepsilon_{i}
$$

Di mana:

$\mathrm{Pi} \quad=$ Probabilitas bahwa peminjam sejahtera berdasarkan persepsi kesejahteraan responden

1-Pi = Probabilitas bahwa peminjam tidak sejahtera berdasarkan persepi kesejahteraan responden

$\mathrm{X}_{1} \quad$ = Lama menjadi anggota (tahun)

$\mathrm{X}_{2}=$ Kepemilikan aset

$\mathrm{X}_{3} \quad$ = Jumlah pembiayaan yang diambil responden (rupiah)

$\mathrm{X}_{4} \quad$ = Pendapatan rata-rata keluarga (rupiah)

$\mathrm{X}_{5} \quad=$ Pengeluaran untuk makanan dari total pendapatan (\%)

$\mathrm{X}_{6} \quad=$ Biaya kesehatan dari total pendapatan (\%)

$\mathrm{X}_{7} \quad=$ Biaya pendidikan dari total pendapatan $(\%)$

$\mathrm{X}_{8} \quad=$ Jumlah tabungan

$\beta_{\tilde{i}} \quad=$ Konstanta

$\mathrm{B} \quad=$ Koefisien estimasi

$\varepsilon_{\mathrm{i}}=$ error

\section{HASIL DAN PEMBAHASAN}

\section{Karakteristik Responden}

Karakteristik responden diklasifikasikan berdasarkan jenis kelamin, usia responden, pendidikan formal terakhir, jenis usaha, dan lama usaha. Karakteristik responden disajikan dalam bentuk tabel untuk mengetahui proporsi dari masing-masing variabel.

Tabel 2 Karakteristik umum responden

\begin{tabular}{llcc}
\hline \multicolumn{1}{c}{ Karakteristik } & Frekuensi & Proporsi (\%) \\
\hline Jenis Kelamin & Perempuan & 15 & 34.88 \\
& Laki-laki & 28 & 65.12 \\
\hline Usia & 20-30 tahun & 4 & 9.30 \\
& 31-40 tahun & 18 & 41.86 \\
& 41-50 tahun & 17 & 39.53 \\
& 51-60 tahun & 4 & 9.30 \\
\hline Pendidikan & Tidak sekolah & 0 & 0.00 \\
& SD/MI/Paket A & 16 & 37.21 \\
& SMP/MTs/Paket B & 9 & 20.93 \\
& SMA/SMK/MA/Paket C & 13 & 30.23 \\
& D1/D3/S1 & 5 & 11.63 \\
\hline
\end{tabular}

Sumber: Data primer, 2020 (diolah)

Pada penelitian ini, responden dengan jenis kelamin laki-laki berjumlah lebih banyak dibandingkan responden dengan jenis kelamin perempuan yaitu berturut-turut $65.12 \%$ dan $34.88 \%$. Mayoritas responden penelitian ini berada pada rentang usia 31-40 tahun yang berjumlah 18 orang dengan proporsi sebesar $41.86 \%$ dari total responden. Tingkat pendidikan terakhir SD/MI/Paket A memiliki jumlah paling banyak dengan proporsi sebesar $37.21 \%$ dari total responden.

\section{Karakteristik Usaha Responden}

Berdasarkan hasil penelitian pada Tabel 3, jenis usaha UMK yang mendapatkan pembiayaan mayoritas bergerak di sektor perdagangan dengan jumlah 20 UMK dengan proporsi sebesar $46.51 \%$ dari total responden penelitian. Selain perdagangan, terdapat usaha yang bergerak di sektor pertanian dan peternakan yang berjumlah 14 unit dengan proporsi sebesar $32.56 \%$ dari total responden. Banyaknya responden yang memiliki usaha pertanian dan peternakan disebabkan wilayah yang 
menjadi objek penelitian ini berada di daerah Lembang, Kabupaten Bandung Barat. Daerah ini merupakan salah satu daerah terbesar penghasil sayuran di Jawa Barat.

Tabel 3 Karakteristik usaha responden

\begin{tabular}{llcc}
\hline \multicolumn{1}{c}{ Karakteristik } & Frekuensi & Proporsi (\%) \\
\hline Jenis Usaha & Perdagangan & 20 & 46.51 \\
& Pertanian dan peternakan & 14 & 32.56 \\
& Jasa & 3 & 6.98 \\
& Industri rumah tangga & 4 & 9.30 \\
& Produksi & 2 & 4.65 \\
\hline Lama Usaha & 1 tahun & 0 & 0.00 \\
& $1-2$ tahun & 6 & 13.95 \\
& $3-5$ tahun & 11 & 25.58 \\
& 6-10 tahun & 14 & 32.56 \\
& $>10$ tahun & 12 & 27.91 \\
\hline
\end{tabular}

Sumber: Data primer, 2020 (diolah)

Lama usaha dari responden pada penelitian ini berkisar antara 1-23 tahun yang dibagi menjadi lima kelas. Mayoritas UMK sudah beroperasi antara 6-10 tahun dengan jumlah 14 unit usaha dan proporsi sebesar $32.56 \%$ dari total responden penelitian ini. Hal ini dikarenakan pemilik usaha yang awalnya mendirikan usaha dari modal pribadi ingin memperluas skala usahanya sehingga dibutuhkan tambahan modal di luar keuntungan usaha dan modal pribadi. Oleh karena itu, pemilik usaha mengajukan pembiayaan ke Ammana Fintek Syariah melalui mitranya yaitu BMT Dana Ukhuwah dan BMT Mitra Madani.

\section{Kondisi Usaha Responden pada Masa Pandemi Covid-19}

Usaha Mikro, Kecil, dan Menengah (UMKM) merupakan salah satu kelompok usaha yang terdampak pandemi Covid-19. Menurut survei Asian Development Bank Institute (2021), sebanyak 48.6\% UMKM di Indonesia mengalami kerugian dan tutup sementara, mayoritas adalah usaha yang menjual kebutuhan sehari-hari, termasuk makanan, minuman dan pariwisata. Hal ini mengakibatkan pendapatan penyedia layanan teknologi finansial (fintech) menurun, termasuk Ammana Fintek Syariah yang memberhentikan penyaluran pembiayaan kepada UMKM melalui KSPPS atau BMT untuk mencegah terjadinya kredit macet atau gagal bayar.

Koperasi Simpan Pinjam dan Pembiayaan Syariah (KSPPS) yang menjadi mitra Ammana dan terdampak Covid-19 adalah BMT Dana Ukhuwah dan BMT Mitra Madani. Selama masa pandemi Covid-19, BMT Dana Ukhuwah kesulitan dalam mengelola likuiditasnya. Sejak Maret 2020, Ammana Fintek Syariah telah menghentikan sementara aktivitas penyaluran dana ke BMT Dana Ukhuwah. Hal ini disebabkan oleh banyaknya angsuran pembiayaan yang belum dibayar oleh penerima pembiayaan (pelaku UMK) akibat usahanya yang terdampak pandemi Covid-19. Akibatnya, BMT Dana Ukhuwah tidak dapat melalukan pencairan terhadap portofolio pengajuan pembiayaan yang baru masuk karena tidak memiliki likuiditas yang cukup. UMK yang menjadi responden dari penelitian ini merupakan anggota dari BMT Dana Ukhuwah yang juga ikut terdampak penyebaran Covid-19. Dampak yang dirasakan oleh pelaku UMK dalam penelitian ini sangat beragam, seperti terdapat pada Tabel 4 .

Tabel 4 Kondisi usah responden pada masa pandemi Covid-19

\begin{tabular}{ccc}
\hline Kondisi Usaha & Frekuensi & Proporsi (\%) \\
\hline Untung & 17 & 39.53 \\
Balik modal (BEP) & 3 & 6.98 \\
Rugi & 23 & 53.49 \\
\hline Total & 43 & 100.00 \\
\hline
\end{tabular}

Sumber: Data primer, diolah (2020)

118 
Berdasarkan hasil penelitian pada Tabel 4, dampak pandemi Covid-19 terhadap keuntungan UMK terbagi menjadi usaha yang tetap mendapatkan keuntungan, usaha yang hanya mampu menutup biaya usaha yang dikeluarkan tanpa mendapatkan keuntungan (Break Event Point), dan usaha yang mengalami kerugian. Dari 43 UMK, terdapat 17 unit usaha yang tetap mendapatkan keuntungan selama masa pandemi Covid-19, 3 usaha yang hanya mampu menutup biaya usaha yang dikeluarkan tanpa mendapatkan keuntungan dan 23 unit usaha mengalami kerugian.

\section{Karakteristik Rumah Tangga Responden}

Pada Tabel 5 ditunjukkan bahwa sebagian besar responden memiliki jumlah pendapatan antara Rp1,000,000.00 sampai Rp5,000,000.00 per bulan dengan jumlah 29 orang dan proporsi sebesar $67.44 \%$ dari total responden. Hal ini disebabkan karena para pelaku usaha belum menerapkan manajemen usaha yang lebih kompleks dan belum memisahkan antara pengeluaran untuk usaha dan pengeluaran kebutuhan sehari-hari keluarga yang dapat mengurangi jumlah pendapatan bersih yang didapatkan setiap bulan. Selain itu, jumlah pendapatan tersebut dipengaruhi oleh faktor eksternal seperti adanya pandemi Covid-19 yang membuat daya beli masyarakat menurun sehingga permintaan pasar rendah yang mengakibatkan harga produk turun drastis, contohnya pada komoditas sayuran.

Tabel 5 Karakteristik rumah tangga responden

\begin{tabular}{llcc}
\hline & \multicolumn{1}{c}{ Karakteristik } & Frekuensi (orang) & Persentase (\%) \\
\hline Rata-rata pendapatan per & $1,000,000-5,000,000$ & 29 & 67.4 \\
Bulan (Rp) & $5,000,0001-10,000,000$ & 11 & 25.58 \\
& $>10,000,000$ & 3 & 6.98 \\
\hline Pengeluaran makanan per & $<10$ & 2 & 4.65 \\
total pendapatan (\%) & $10-30$ & 12 & 27.91 \\
& $31-50$ & 17 & 39.53 \\
& $>50$ & 12 & 27.91 \\
\hline Pengeluaran kesehatan per & $<5$ & 24 & 55.81 \\
total pendapatan (\%) & $5-10$ & 14 & 32.56 \\
& $11-20$ & 1 & 2.33 \\
& $21-30$ & 2 & 4.65 \\
& $>30$ & 2 & 4.65 \\
\hline Pengeluaran kesehatan per & $<5$ & 4 & 9.30 \\
total pendapatan (\%) & $5-10$ & 12 & 27.91 \\
& $11-20$ & 12 & 27.91 \\
& $21-30$ & 9 & 20.93 \\
& $>30$ & 6 & 13.95 \\
\hline Jumlah tabungan responden & $<50,000$ & 10 & 23.26 \\
(dalam Rp) & $50,000-100,000$ & 3 & 6.98 \\
& $100,001-500,000$ & 18 & 41.86 \\
& $500.001-1,000,000$ & 5 & 11.63 \\
& $1,000,001-3,000,000$ & 6 & 13.95 \\
& $>3,000,000$ & 1 & 2.33 \\
\hline
\end{tabular}

Sumber: Data primer, 2020 (diolah)

Pengeluaran makanan keluarga per bulan sangat beragam proporsinya antara 9-70\% dari total pendapatan keluarga per bulan. Berdasarkan Tabel 5, mayoritas responden menghabiskan 31-50 persen pendapatan untuk belanja makanan sehari-hari. Hasil tersebut menunjukkan bahwa mayoritas responden yang berjumlah 17 orang mampu membagi alokasi pendapatan antara pengeluaran untuk membeli makanan dengan pengeluaran untuk membeli kebutuhan lainnya, seperti biaya pendidikan, kesehatan, dan listrik. 
Pengeluaran untuk perawatan kesehatan per bulan keluarga sangat beragam yang dibagi menjadi lima kelas klasifikasi. Besar proporsinya antara 0-33\% dari total pendapatan keluarga per bulan. Berdasarkan Tabel 5, mayoritas responden mengeluarkan kurang dari 5\% pendapatan untuk perawatan kesehatan. Hasil tersebut menunjukkan bahwa mayoritas responden yang berjumlah 24 orang menghabiskan sangat sedikit pengeluaran untuk perawatan kesehatan. Dari 24 orang responden, 16 orang di antaranya menjadi Penerima Bantuan Iuran Jaminan Kesehatan (PBI JK) atau mendapatkan jaminan sosial ketenagakerjaan dari kantor tempat suami/istrinya bekerja sehingga tidak mengeluarkan biaya sama sekali untuk melakukan pengobatan atau perawatan kesehatan.

Pengeluaran untuk biaya pendidikan per bulan keluarga juga sangat beragam, proporsinya antara 0$37.5 \%$ dari total pendapatan keluarga per bulan yang digunakan antara lain untuk membayar biaya sekolah, membeli seragam, alat tulis, serta uang jajan anak. Berdasarkan Tabel 5, mayoritas keluarga responden menghabiskan 5-10\% dari total pendapatan untuk keperluan pendidikan. Hasil tersebut menunjukkan bahwa 12 orang responden menghabiskan sedikit pengeluaran untuk biaya pendidikan. Hal tersebut disebabkan $27.91 \%$ dari total responden hanya mengeluarkan biaya pendidikan untuk anggota keluarga yang duduk di bangku Taman Kanak-Kanak (TK) dan Sekolah Dasar (SD). Selain itu, responden yang menghabiskan $11-20 \%$ pengeluaran dari total pendapatan untuk biaya pendidikan berjumlah 12 orang. Hal tersebut disebabkan responden mengeluarkan biaya pendidikan untuk anggota keluarga yang duduk di bangku Sekolah Dasar (SD) dan Sekolah Menengah Pertama (SMP).

Berdasarkan hasil penelitian pada Tabel 5, ditunjukkan bahwa jumlah tabungan mayoritas responden antara Rp100,000.00 sampai Rp500,000.00 dengan jumlah sebanyak 18 orang dan proporsi sebesar $41.86 \%$ dari total responden. Hal ini dikarenakan mayoritas responden penelitian ini memiliki jumlah pendapatan per bulan berkisar antara Rp1,000,000.00 sampai Rp5,000,000.00 sehingga proporsi tabungan yang disisihkan oleh responden tidak terlalu besar karena pengeluaran kebutuhan sehari-hari sudah mengambil lebih dari $75 \%$ total pendapatan responden.

\section{Dampak Pembiayaan Peer-to-Peer Lending Syariah terhadap Perubahan Jumlah Omzet Usaha, Keuntungan, Biaya Usaha, dan Tenaga Kerja UMK}

Dampak pembiayaan peer-to-peer lending syariah terhadap perubahan jumlah omzet usaha, keuntungan, biaya usaha, dan tenaga kerja dapat dilihat melalui hasil uji beda berpasangan. Hasil uji-t berpasangan pada Tabel 6 menggunakan taraf nyata 5\% two tailed $(\mathrm{a}=5 \%)$ dan $10 \%(\mathrm{a}=10 \%)$ dengan jumlah data sebanyak 43 responden. Pada variabel jumlah omzet usaha menunjukkan hasil yang signifikan pada taraf nyata $5 \%$ dengan nilai probabilitas ( $p$-value) sebesar 0.027. Artinya, terdapat perbedaan antara rata-rata jumlah omzet usaha sebelum mendapatkan pembiayaan yaitu sebesar Rp12,336,395.37 dengan rata-rata omzet usaha setelah mendapatkan pembiayaan yaitu sebesar Rp18,926,744.19. Hasil tersebut menunjukkan bahwa pembiayaan yang didapatkan dari $P 2 P$ lending syariah mampu meningkatkan jumlah omzet usaha yang diperoleh UMK.

Tabel 6 Perubahan jumlah omzet usaha, keuntungan, biaya usaha, dan tenaga kerja setelah mendapatkan pembiayaan peer-to-peer lending syariah (dalam $\mathrm{Rp}$ )

\begin{tabular}{lcccc}
\hline \multirow{2}{*}{ Variabel } & \multicolumn{4}{c}{ Mean } \\
\cline { 2 - 5 } \multicolumn{1}{c}{ Sebelum } & Sesudah & Selisih & $\boldsymbol{P}$-value \\
\hline Omzet Usaha (Rp) & $12,336,395.37$ & $18,926,744.19$ & $6,590,348.81$ & $0.027^{*}$ \\
Keuntungan (Rp) & $4,811,918.63$ & $6,881,162.79$ & $2,069,244.16$ & $0.016^{*}$ \\
Biaya Usaha (Rp) & $7,524,476.74$ & $12,045,581.40$ & $4,521,104.65$ & $0.045^{*}$ \\
Jumlah Tenanga & 1.86 & 2.67 & 0.814 & $0.057^{* *}$ \\
Kerja (orang) & & &
\end{tabular}

Keterangan: *) signifikan pada taraf nyata $5 \%$

**) signifikan pada taraf nyata $10 \%$

Selisih: Perbedaan rata-rata setiap variabel sebelum dan sesudah mendapatkan pembiayaan

Sumber: Data primer, 2020 (diolah) 
Hasil uji-t berpasangan untuk variabel jumlah keuntungan menunjukkan hasil yang signifikan pada taraf nyata 5\%. dengan nilai probabilitas ( $p$-value) sebesar 0.016. Artinya, terdapat perbedaan antara rata-rata jumlah keuntungan sebelum mendapatkan pembiayaan yaitu sebesar Rp4,811,918.63 dengan rata-rata jumlah keuntungan setelah mendapatkan pembiayaan yaitu sebesar Rp6,881,162.79. Hasil tersebut menunjukkan bahwa pembiayaan yang didapatkan dari $P 2 P$ lending syariah mampu meningkatkan jumlah keuntungan usaha yang diperoleh UMK.

Biaya usaha adalah biaya yang dikeluarkan oleh UMKM untuk membeli bahan baku, barang-barang usaha dan untuk membayar biaya operasional usaha. Hasil uji-t berpasangan variabel jumlah biaya usaha menunjukkan hasil yang signifikan pada taraf nyata 5\%. Hal ini dibuktikan oleh nilai probabilitas $(p$-value $)$ sebesar 0.045 atau kurang dari $0.05(\mathrm{a}=5 \%)$. Terdapat perbedaan antara ratarata biaya usaha antara sebelum mendapatkan pembiayaan yaitu sebesar Rp7,524,476.74 dengan ratarata biaya usaha yaitu sebesar Rp,12,045,581.40. Hasil tersebut menunjukkan bahwa pembiayaan yang didapatkan dari peer-to-peer lending syariah mampu meningkatkan biaya usaha UMK.

Hasil uji-t berpasangan untuk variabel jumlah tenaga kerja menunjukkan hasil yang signifikan pada taraf nyata $10 \%$. Hal ini dibuktikan oleh nilai probabilitasnya sebesar 0.057 atau kurang dari $0.1(\mathrm{a}=$ $10 \%)$. Terdapat perbedaan antara rata-rata jumlah tenaga kerja sebelum mendapatkan pembiayaan yaitu sebanyak 1.86 dengan rata-rata jumlah tenaga kerja setelah mendapatkan pembiayaan yaitu sebanyak 2.67. Hasil tersebut menunjukkan bahwa pembiayaan yang didapatkan dari peer-to-peer lending syariah mampu meningkatkan jumlah tenaga kerja yang dibutuhkan oleh UMK.

\section{Faktor-Faktor yang Memengaruhi Perubahan Keuntungan UMK Setelah Mendapatkan Pembiayaan Peer-to-Peer Lending Syariah}

Uji asumsi klasik dilakukan untuk memenuhi asumsi BLUE pada OLS. Uji asumsi klasik terdiri dari uji normalitas, heteroskedastisitas, autokorelasi, dan uji multikolinearitas. Uji normalitas menggunakan uji Shapiro-wilk dengan nilai probabilitas ( prob $>$ z) sebesar 0.36396 atau lebih besar dari 0.05 (taraf nyata 5\%), artinya asumsi residual model pengaruh pembiayaan peer-to-peer lending syariah terhadap perubahan keuntungan UMK tersebar normal terpenuhi.

Uji heteroskedastisitas menggunakan uji Breusch-Pagan menunjukkan nilai probabilitas (Prob > chi2) sebesar 0.1146 atau lebih besar dari 0.05 (taraf nyata 5\%) sehingga dapat disimpulkan bahwa asumsi homogenitas pada model penelitian ini terpenuhi. Uji autokorelasi menggunakan uji Breusch-Godfrey $L M$ menunjukkan nilai probabilitas (prob > chi2) sebesar 0.8696 atau lebih besar dari 0.05 (taraf nyata $5 \%$ ) sehingga dapat disimpulkan bahwa tidak terdapat autokorelasi pada model penelitian ini. Nilai VIF dari masing-masing variabel yang digunakan pada model penelitian ini kurang dari $10(<10)$. Artinya, tidak terdapat korelasi antar variabel independen dalam model penelitian ini atau pada model penelitian ini tidak terdapat masalah multikolinearitas.

Hasil pengolahan menggunakan metode Ordinary Least Square (OLS) menunjukkan nilai $R$-square sebesar 0.5693 keragaman nilai perubahan keuntungan usaha mampu dijelaskan oleh variabel-variabel dalam model, sedangkan $43.07 \%$ sisanya dijelaskan oleh variabel lain di luar model. Berdasarkan hasil analisis pada Tabel 7, variabel jumlah pembiayaan signifikan dan berpengaruh positif terhadap perubahan keuntungan UMK pada taraf nyata $1 \%$ serta variabel biaya usaha, lama usaha dan jumlah tenaga kerja signifikan dan berpengaruh positif terhadap perubahan keuntungan UMK pada taraf nyata $5 \%$. Sedangkan variabel dummy pendidikan dan frekuensi pembiayaan tidak berpengaruh signifikan terhadap perubahan keuntungan UMK. 
Tabel 7 Faktor-faktor yang Memengaruhi Perubahan Keuntungan UMK

\begin{tabular}{lccc}
\hline \multicolumn{1}{c}{ Variabel } & Coefficient & t-value & P>|t| \\
\hline Constant & -1.4934 & -0.37 & 0.711 \\
Ln_pembiayaan & 0.8719 & 3.27 & $0.002^{*}$ \\
Ln_biaya usaha & 0.0609 & 2.20 & $0.035^{* *}$ \\
Jumlah tenaga kerja & 0.1567 & 2.13 & $0.040^{* *}$ \\
Lama usaha & 0.3754 & 2.38 & $0.023^{* *}$ \\
Dummy Pendidikan & 0.0681 & 0.22 & 0.826 \\
Frekuensi pembiayaan & -0.0584 & -1.26 & 0.214 \\
\hline
\end{tabular}

R-Squared: $56.93 \%$
Keterangan: ${ }^{*}$ ) Signifikan pada taraf nyata $1 \%$
$* *$ Signifikan pada taraf nyata $5 \%$

Sumber: Data primer, 2020 (diolah)

Variabel jumlah pembiayaan memiliki pengaruh positif terhadap perubahan keuntungan usaha setelah mendapatkan pembiayaan peer-to-peer lending syariah dengan nilai probabilitas sebesar 0.002 atau signifikan pada taraf nyata $1 \%$. Nilai koefisien parameter variabel jumlah pembiayaan sebesar 0.8719 . Artinya, peningkatan biaya usaha sebesar $1 \%$ akan meningkatkan omzet usaha sebesar $0.8719 \%$, ceteris paribus. bahwa UMK dapat memanfaatkan pembiayaan yang telah didapatkannya sebagai modal tambahan untuk meningkatkan kegiatan produktivitas usahanya sehingga mampu meningkatkan keuntungan usaha yang diperoleh. Hasil ini sesuai dengan penelitian Tunas et al. (2014) yang menyatakan bahwa besarnya pembiayaan yang didapatkan UMK berpengaruh positif terhadap perubahan keuntungan usaha karena semakin bertambahnya modal untuk melakukan atau meningkatkan aktivitas produktif sehingga mampu meningkatkan omzet usaha yang berdampak pada peningkatan keuntungan.

Variabel biaya usaha berpengaruh positif signifikan terhadap perubahan keuntungan usaha UMK setelah mendapatkan pembiayaan peer-to-peer lending syariah dengan nilai probabilitas sebesar 0.035 atau signifikan pada taraf nyata 5\%. Nilai koefisien parameter variabel jumlah pembiayaan sebesar 0.0609. Artinya, peningkatan jumlah biaya usaha sebesar $1 \%$ akan meningkatkan keuntungan usaha UMK sebesar $0.0609 \%$, ceteris paribus. Hasil tersebut menunjukkan bahwa semakin besar jumlah biaya usaha yang digunakan dapat meningkatkan omzet usaha karena dapat meningkatan persediaan produk dan porsi belanja bahan baku untuk produksi, sehingga keuntungan usaha juga meningkat. Hasil ini sejalan dengan penelitian Nurdana (2018) yang menyatakan bahwa biaya usaha memiliki pengaruh yang positif terhadap peningkatan omzet usaha.

Variabel jumlah tenaga kerja berpengaruh positif signifikan terhadap perubahan keuntungan UMK setelah mendapatkan pembiayaan dengan nilai probabilitas sebesar 0.040 atau signifikan pada taraf nyata $5 \%$. Nilai koefisien parameter jumlah tenaga kerja sebesar 0.1567 . Artinya, peningkatan jumlah tenaga kerja sebesar 1 orang akan meningkatkan omzet usaha UMK sebesar $0.1567 \%$, ceteris paribus. Hasil tersebut menunjukkan bahwa penambahan tenaga kerja akan meningkatkan produktivitas usaha untuk membantu dalam hal produksi dan operasional usaha. Dampaknya, terjadi peningkatan produksi usaha yang dapat meningkatkan volume penjualan dan peningkatan omzet UMK yang juga meningkatkan keuntungan usaha.

Hasil tersebut sejalan dengan hasil penelitian Nurdana (2018), Amrani et al. (2018) dan Tunas et al. (2014) yang menunjukkan bahwa jumlah tenaga kerja berpengaruh positif terhadap omzet usaha mikro. Tenaga kerja memainkan peran sangat penting dalam menghasilkan output bagi perusahaan, sehingga dapat meningkatkan produktivitas usaha yang secara tidak langsung akan meningkatkan omzet dan keuntungan usaha.

Variabel lama usaha berpengaruh positif signifikan terhadap perubahan keuntungan UMK setelah mendapatkan pembiayaan dengan nilai probabilitas sebesar 0.023 atau signifikan pada taraf nyata $5 \%$. 
Nilai koefisien parameter lama usaha sebesar 0.3754. Artinya, semakin lama suatu usaha berdiri dan beroperasi maka semakin baik pula strategi yang dimilikinya untuk meningkatkan volume penjualan yang berdampak pada peningkatan omzet usaha. Peningkatan omzet usaha secara langsung akan meningkatkan keuntungan usaha Hal ini terjadi karena usaha yang beroperasi terlebih dahulu telah melakukan riset pasar dan mendapatkan informasi pangsa pasar yang lebih banyak dibandingkan dengan usaha yang baru beroperasi. Selain itu, usaha yang telah lama beroperasi sudah memiliki segmen pelanggan tersendiri yang telah menggunakan produk yang dijual atau dihasilkan oleh UMK.

Hasil tersebut sejalan dengan penelitian Nurdana (2018), Hidayati et al. (2014) dan Tunas et al. (2014) yang menyatakan bahwa lama usaha berpengaruh positif terhadap perkembangan usaha. Pelaku usaha yang telah mendirikan bisnis terlebih dahulu memiliki kemampuan untuk meningkatkan strategi dalam mengelola usaha dan mampu menyesuaikan usaha dengan kondisi pasar.

\section{Faktor-Faktor yang Memengaruhi Kesejahteraan Pelaku UMK Berdasarakan Opini Responden}

Model regresi logistik pada penelitian digunakan untuk melihat faktor-faktor yang memengaruhi kesejahteraan pelaku UMK yang telah mendapatkan pembiayaan peer-to-peer lending dari Ammana Fintek Syariah. Kesejahteraan pelaku UMK dinilai berdasarkan skor presepsi kesejahteraan yang terdapat pada kuesioner dan telah diisi oleh responden UMK. Hasil pendugaan parameter logistik terhadap kesejahteraan pelaku UMK yang disajikan pada Tabel 8 dan Tabel 9.

Tabel 8 menunjukkan hasil pendugaan parameter logistik yang menjelaskan ketepatan dari hasil pendugaan oleh model. Hasil pendugaan mengklasifikasikan responden yang menyatakan dirinya tidak sejahtera sebanyak 10 orang atau sebesar $50 \%$ di mana 5 orang dari total yang menyatakan tidak sejahtera diklasifikasikan sebagai responden tidak sejahtera oleh model, sedangkan 5 orang lainnya dinyatakan sejahtera oleh model.

Berikutnya, hasil pendugaan model mengklasifikasikan responden yang menyatakan dirinya sejahtera berjumlah 33 orang atau sebesar $100 \%$ di mana 33 orang responden tersebut dinyatakan sejahtera oleh model. Model pendugaan parameter yang digunakan pada penelitian ini sudah tepat. Hal ini dibuktikan oleh uji Hosmer and Lemeshow menunjukkan nilai Chi-square sebesar 7.737 atau lebih kecil daripada Chi-square tabel 15.507 dan nilai signifikan 0.45 atau lebih besar dari 0.05 (taraf nyata $5 \%$ ). Artinya, model penelitian yang digunakan cukup mampu menjelaskan faktor-faktor yang memengaruhi kesejahteraan pelaku UMK. Selain itu, nilai Pseudo $R$-Square pada model penelitian ini dapat dilihat dari nilai Nagelkerke R-Square sebesar 0.45 atau $45 \%$ keragaman nilai probabilitas kesejahteraan dapat dijelaskan oleh variabel-variabel bebas dalam model, sedangkan sisanya dijelaskan oleh variabel lain di luar model.

Tabel 8 Hasil pendugaan parameter logistik terhadap kesejahteraan responden

\begin{tabular}{ccccc}
\hline \multirow{2}{*}{ Observed } & & \multicolumn{3}{c}{ Predicted } \\
\cline { 3 - 3 } & & \multicolumn{2}{c}{$\begin{array}{c}\text { Persepsi Responden tentang } \\
\text { Kesejahteraan }\end{array}$} & Percentage \\
& & $\begin{array}{c}\text { Tidak } \\
\text { Sejahtera }\end{array}$ & Sejahtera & Correct \\
\cline { 2 - 3 } & & 5 & 5 & 50.5 \\
Persepsi Responden & Tidak Sejahtera & 0 & 33 & 100 \\
\hline tentang Kesejahteraan & Sejahtera & & & 88.4 \\
\hline Overall percentage & & & & \\
\hline
\end{tabular}

Sumber: Data primer, 2020 (diolah)

Pada Tabel 9 ditunjukkan hasil pendugaan parameter model regresi logistik untuk menganalisis faktor-faktor yang memengaruhi kesejahteraan pelaku UMK yang telah mendapatkan pembiayaan. Variabel yang signifikan memengaruhi kesejahteraan pelaku UMK pada taraf nyata 5\% adalah jumlah 
tabungan, sedangkan variabel pendapatan rata-rata keluarga signifikan memengaruhi kesejahteraan pelaku UMK pada taraf nyata $10 \%$.

Tabel 9 Faktor-faktor yang memengaruhi kesejahteraan pelaku UMK

\begin{tabular}{|c|c|c|c|c|c|c|}
\hline Variabel & $\boldsymbol{B}$ & Std.Error & Wald & $D f$ & Sig & $\begin{array}{l}\text { Odds Ratio } \\
\operatorname{Exp}(B)\end{array}$ \\
\hline Konstanta & -51.617 & 29.950 & 3.668 & 1 & 0.055 & 0.000 \\
\hline Lama Anggota & -0.091 & 0.179 & 0.259 & 1 & 0.611 & 0.913 \\
\hline Kepemilikan Aset & -0.299 & 0.446 & 0.448 & 1 & 0.503 & 0.742 \\
\hline Jumlah Pembiayaan & -0.626 & 0.900 & 0.399 & 1 & 0.527 & 0.535 \\
\hline $\begin{array}{l}\text { Pendapatan Rata - Rata } \\
\text { Keluarga }\end{array}$ & 3.956 & 2.056 & 3.701 & 1 & $0.054^{* *}$ & 52.265 \\
\hline Pengeluaran Makanan & 0.055 & 0.048 & 1.332 & 1 & 0.248 & 1.056 \\
\hline Biaya Kesehatan & 0.099 & 0.083 & 1.427 & 1 & 0.232 & 1.104 \\
\hline Biaya Pendidikan & 0.016 & 0.039 & 0.170 & 1 & 0.680 & 1.016 \\
\hline Tabungan & 0.230 & 0.106 & 4.718 & 1 & $0.030 *$ & 1.259 \\
\hline $\begin{array}{l}\text { Pseudo R-Square } \\
\text { 2log likelihood } \\
\text { Overall Accuracy }\end{array}$ & & & & & & $\begin{array}{c}0.450 \\
31.433 \\
88 \%\end{array}$ \\
\hline
\end{tabular}

Keterangan: *) Siginifikan pada taraf nyata 5\%

**)Signifikan pada taraf nyata $10 \%$

Sumber: Data primer, 2020 (diolah)

Variabel pendapatan rata-rata keluarga positif signifikan memengaruhi kesejahteraan pelaku UMK. Nilai odds ratio variabel pendapatan rata-rata keluarga sebesar 52.265. Artinya, semakin tinggi jumlah pendapatan rata-rata pelaku usaha mikro dan kecil (UMK) maka pelaku usaha berpeluang 52.265 kali lebih sejahtera, ceteris paribus Hal ini dikarenakan semakin tinggi jumlah pendapatan yang diterima, maka semakin banyak kebutuhan pelaku usaha dan keluarga yang dapat dipenuhi serta dapat dialokasikan untuk aktivitas produktif seperti ekspansi usaha. Hasil penelitian ini sesuai dengan penelitian Gina dan Effendi (2015) yang menyatakan bahwa semakin tinggi jumlah pendapatan yang diterima sebuah rumah tangga, maka semakin besar anggaran rumah tangga dan kebutuhan sehari-hari yang dapat dipenuhi.

Variabel jumlah tabungan positif signifikan memengaruhi kesejahteraan pelaku UMK. Nilai odds ratio variabel jumlah tabungan sebesar 1.259, artinya responden dengan jumlah tabungan lebih besar berpeluang 1.259 kali lebih sejahtera dibandingkan dengan responden yang memiliki jumlah tabungan lebih sedikit, ceteris paribus. Hal ini karena tabungan merupakan salah satu indikator yang menentukan apakah seseorang dikategorikan sebagai masyarakat miskin atau tidak. Menurut Kemensos, apabila seseorang memiliki tabungan atau barang yang dapat dijual dengan nilai minimal sebesar 500,000 rupiah, maka orang tersebut termasuk dalam masyarakat sejahtera. Penelitian ini sesuai dengan penelitian yang dilakukan Khoerunnisa (2016) bahwa semakin besar kemampuan menabung yang dimiliki responden maka semakin meningkat kesejahteraan yang dialaminya.

\section{SIMPULAN}

Berdasarkan hasil estimasi uji beda berpasangan dan output OLS pembiayaan dari P2P lending syariah memiliki pengaruh positif dan signifikan terhadap kinerja UMK yang diukur melalui perubahan omzet dan keuntungan pelaku usaha. Hal tersebut dibuktikan dengan adanya kenaikan yang signifikan pada masing-masing variabel antara sebelum dan setelah mendapatkan pembiayaan peer-to-peer lending syariah. Kinerja UMK yang diukur melalui perubahan omzet dan keuntungan juga dipengaruhi oleh variebal lain seperti biaya usaha, lama usaha dan jumlah tenaga kerja. Tetapi, selama masa pandemi Covid-19 mayoritas UMK pada penelitian ini terdampak dan mengalam 
kerugian yang diakibatkan oleh penurunan omzet usaha hingga 50-70\% dari jumlah omzet usaha yang biasa diperoleh, harga produk yang anjlok, bahkan usaha yang tidak beroperasi sama sekali.

Hasil analisis regresi logistik menunjukkan bahwa variabel pendapatan rata-rata berpengaruh signifikan positif terhadap kesejahteraan pelaku UMK. Semakin tinggi jumlah pendapatan yang diterima, maka semakin banyak kebutuhan pelaku usaha dan keluarga yang dapat dipenuhi serta dapat dialokasikan untuk aktivitas produktif seperti ekspansi usaha. Selain itu, variabel jumlah tabungan juga berpengaruh signifikan positif terhadap kesejahteraan pelaku UMK. Tabungan merupakan salah satu indikator yang menentukan apakah seseorang dikategorikan sebagai masyarakat miskin atau tidak. Pada masa pandemi Covid-19 ini kondisi usaha responden juga terdampak, di mana sebanyak $53.49 \%$ mengalami kerugian, dan hanya $39.53 \%$ yang memperoleh keuntungan.

Untuk penelitian selanjutnya, peneliti dapat menambahkan variabel kontrol berupa UMK yang tidak mendapatkan pembiayaan peer-to-peer lending syariah untuk membandingkan pengaruh pembiayaan yang lebih detail dan signifikan terhadap kinerja UMK. Dalam mengukur kesejahteraan pelaku UMK sebaiknya ditambahkan indikator-indikator lain yang lebih spesifik seperti kondisi tempat tinggal, fasilitas MCK yang tersedia, atau indikator lainnya untuk mengukur kesejahteraan pelaku UMK agar mendapatkan hasil pengukuran tingkat kesejahteraan yang lebih akurat. Selain itu, gunakan variabel pendapatan rata-rata per kapita responden sehingga lebih objektif dalam mengukur kesejahteraan responden.

\section{DAFTAR PUSTAKA}

[ADBI] Asian Development Bank Institute. (2021). The Impacts of the Covid-19 Pandemic on Micro, Small, and Medium Enterprises in Asia and Their Digitalization Responses [Internet]. [diunduh 2021 Mar 8]. Tersedia pada: https://www.adb.org/sites/default/files/publication/692466/adbiwp1241.pdf.

[Ammana] Ammana.id. (2020). Financing [Internet]. [diakses 2020 Nov 19]. Tersedia pada: https://ammana.id/.

Amrani, M. B. S, Hamza, F. \& Mosthapa, E.H. (2018). A modeling study of the micro-finance impact on the economic performance of micro-enterprises and well-being of borrowers in Morocco: Case of Tangier-Tetouan-Al Hoceima regionitle. International Journal of Economics and Financial Issues, 8(5), 243-250.

Aragón-Sánchez, A. \& Sánchez-Marín, G. (2005). Strategic orientation, management characteristics, and performance: A study of Spanish SMEs. Journal of Small Business Management, 43(3), 287-308.

Baihaqi J. (2018). Financial technology peer-to-peer lending berbasis syariah di Indonesia. TAWAZUN: Journal of Sharia Economic Law, 1(2), 116-132.

[Bappenas] Badan Perencanaan Pembangunan Nasional. (2018). Masterplan Ekonomi Syariah Indonesia 2019-2024 [Internet]. [diunduh 2019 Des 27]. Tersedia pada: https://knks.go.id/storage/upload/1573459280-Masterplan\%20Eksyar_Preview.pdf.

[BI] Bank Indonesia. (2017). Teknologi Finansial (Fintech) [Internet]. [diunduh 2020 Apr 15]. Tersedia pada: https://www.bi.go.id/id/fungsi-utama/sistem-pembayaran/ritel/financialtechnology/default.aspx.

[BPPP Kemendag] Badan Pengkajian dan Pengembangan Kebijakan Perdagangan Kementerian Perdagangan. (2013). Analisis Peran Lembaga Pembiayaan dalam Pengembangan UMKM [Internet]. [diunduh 2020 Nov 17]. Tersedia pada: http://bppp.kemendag.go.id/ media_content/2017/08/ANALISIS_PERAN_LEMBAGA_PEMBIAYAAN_DALAM_PENG EMBANGAN_UMKM.pdf.

[BPS] Badan Pusat Statistik. (2016). Potensi Usaha Mikro Kecil Sensus Ekonomi 2016 [Internet]. [diunduh 2020 Apr 15]. Tersedia pada: https://www.bps.go.id/publication/2018/12/31/ e3e59cd2b44229814b5a7176/potensi-usaha-mikro-kecil-sensus-ekonomi-2016.html. 
Firdaus, M., Harmini \& Farid. (2011). Aplikasi Metode Kuantitatif untuk Manajemen dan Bisnis. Bogor (ID), IPB Press.

Gina, W. \& Effendi, J. (2015). Program pembiayaan lembaga keuangan mikro syariah (LKMS) dalam peningkatan kesejahteraan pelaku usaha mikro (studi kasus BMT Baitul Karim Bekasi). AlMuzara'ah, 3(1), 34-43.

Giudici, P. (2018). Fintech risk management: A research challenge for artificial intelligence in finance. Frontiers in Artificial Intelligence, 1(1), 1-5.

Greiner, M. E. \& Wang, H. (2009, December). The role of social capital in people-to-people lending market place. In Proceedings of the $4^{\text {th }}$ International of Conference on Information Systems.

Gujarati, D. N. \& Porter, D.C. (2009). Basic Econometric 5th Edition. New York (USA), McGraw Hill.

Hidayati, N., Widyastutik \& Wiliasih, R. (2014). Faktor-faktor yang memengaruhi realisasi pembiayaan mikro syariah dan dampaknya terhadap omzet usaha nasabah: Studi kasus KJKS BMT UGT Sidogiri cabang Koja Jakarta. Al-Muzara'ah, 2(1), 54-74.

[Kemenko Perekonomian RI] Kementerian Koordinator Bidang Perekonomian Republik Indonesia. (2020). Data Realisasi KUR [Internet]. [diakses 2020 Okt 15]. Tersedia pada: https://kur.ekon.go.id/realisasi_kur/2020/10.

[Kemenkop UKM] Kementerian Koperasi dan Usaha Kecil dan Menengah. (2018). Perkembangan Data Usaha Mikro, Kecil, Menengah (UMKM), dan Usaha Besar (UB) [Internet]. [diunduh 2020 Apr 18]. Tersedia pada: https://www.kemenkopukm.go.id/uploads/laporan/1580223129_ PERKEMBANGAN\%20DATA\%20USAHA\%20MIKRO,\%20KECIL, \%20MENENGAH\% 20( UMKM)\%20DAN\%20USAHA\%20BESAR\%20(UB)\%20TAHUN\%202017\%20-\%202018.pd f.

Khoerunnisa. (2016). Dampak Program Simpan Pinjam Perempuan terhadap Tingkat Kesejahteraan Rumah Tangga di Desa Teja Kabupaten Majalengka. (Skripsi, Institut Pertanian Bogor, Bogor, Indonesia).

Nugroho. (2005). Strategi Jitu Memilih Metode Statistik Penelitian dengan SPSS. Yogyakarta(ID), Andi Offset.

Nurdana, D. P. P. (2018). Analisis Dampak Pinjaman Peer-to-Peer (P2P) Lending terhadap Perkembangan Bisnis UMKM. (Skripsi, Institut Pertanian Bogor, Bogor, Indonesia).

Nurkse, R. (1953). Problems of Capital Formation in Underdeveloped Countries. Oxford (UK), Oxford University Press.

[OJK] Otoritas Jasa Keuangan. (2020). Perkembangan Fintech Lending (Pendanaan Gotong Royong) [Internet]. [diunduh 2020 April 13]. Tersedia pada: https://www.ojk.go.id/id/kanal/iknb/datadan-statistik/fintech/Documents/Perkembangan\%20Fintech\%20Lending\%20Periode\%20Maret $\% 202020 . p d f$.

Pei-Wen, T., Zariyawati, M. A., Diana-Rose, F. \& Annuar, M. N. (2016). Impact of microfinance facilities on performance of small medium enterprises in Malaysia. World Applied Sciences Journal, 34(12), 1845-1849.

Rachbini, D. J. \& Hamid A. (1994). Ekonomi Informal Perkotaan: Gejala Involusi Gelombang Kedua. Jakarta (ID), LP3ES.

Rokhayati, I. (2015). Pengukuran kinerja pada usaha mikro kecil dan menengah (UMKM): Suatu telaah pustaka. Monex, 4(2): 94-98.

Sari, D. K., Haryono, D. \& Rosanti, N. (2014). Analisis pendapatan dan tingkat kesejahteraan rumah tangga petani jagung di Kecamatan Natar Kabupaten Lampung Selatan. Jurnal Ilmu-Ilmu Agribisnis, 2(1), 64-70.

Sekaran, U. (2003). Research Method of Business: A Skill-Building Approach. New York (US), John Wiley \& Sons.

Singarimbun, M. \& Efendi, S. (1995). Metode Penelitian Survai. Jakarta (ID), LP3ES.

Studenmund A. H. \& Johnson, B. K. (2016). A Practical Guide to Using Econometrics. Harlow (UK), Harlow Pearson Education Limited.

Sumarwan, U., Daryanto, A., Achsani, N.A., Fahmi, I., Nuryantono, N et al. (2014). Metode Riset Bisnis dan Konsumen. Sumarwan U, editor. Bogor (ID), IPB Press. 
Tampubolon, H. R. (2019). Seluk beluk peer to peer lending sebagai wujud baru keuangan di Indonesia. Jurnal Bina Mulia Hukum, 3(2), 188-198.

Tunas, A. P., Anggraeni, L. \& Lubis, D. (2014). Analisis pengaruh pembiayaan syariah terhadap perkembangan usaha mikro kecil menengah di Kota Depok. Al-Muzara'ah, 2(1), 1-16.

Wang, X. (2013). The Impact of Microfinance on the Development of Small and Medium Enterprises: The Case of Taizhou, China. (Thesis, The Johns Hopkins University, Baltimore, Maryland, USA.

Wijaya, R. (2016). P2P Lending sebagai Wujud Baru Inklusi Keuangan [Internet]. [diakses 2020 Okt 20]. Tersedia pada: https://money.kompas.com/read/2016/11/26/060000226/.p2p.lending. sebagai.wujud.baru.inklusi.keuangan. 